\title{
Keskustelua, itsekritiikkiä ja ihmisenä kasvamista
}

\author{
Aikuiskasvatuksen tutkijatapaaminen osoitti tieteenalan \\ elinvoimaisuuden ja tarpeellisuuden. Tapaamiseen mahtui \\ myös kriittistä keskustelua aikuiskasvatuksen nykytilasta ja \\ tulevaisuuden tutkimustarpeista.
}

- IHMISIÄ ASETETAAN yhä enemmän vastuuseen omasta elämästään, työkykynsä ylläpitämisestä ja itsensä kehittämisestä. Mistä kaikkien näiden paineiden keskellä voi löytää mielekkyyttä elämään? Kysyi Aikuiskasvatuksen Tutkimusseuran esihenkilö, dosentti Karin Filander tutkijatapaamisen avajaispuheessaan.

Vastaukseksi hän tarjosi osallistumista aikuiskasvatukseen ja -koulutukseen, jotka lisäävät tunnetta elämänhallinnasta ja ylläpitävät toivoa paremmasta.

Joka toinen vuosi järjestettävä Aikuiskasvatuksen tutkijatapaaminen kokosi helmikuussa Turkuun yli 130 osanottajaa. Tutkijatapaamisen luotsasi alkuun kasvatustieteiden laitoksen johtaja, professori Risto Rinne. Pääpuhujina kaksipäiväisessä tapaamisessa olivat professori Martin Lawn Oxfordin ja Edinburghin yliopistoista ja professori Anja Heikkinen Tampereen yliopistosta.
ISON-BRITANNIAN ARMEIJAN ASEENA

\section{HENKINEN KEHITYS}

Lawnin omaperäinen luento käsitteli aikuiskoulutuksen uudenlaisten käytäntöjen muotoutumista Ison-Britannian armeijassa toisen maailmansodan kriisiolosuhteissa. Alkusysäyksen uudelle aikuiskoulutusohjelmalle loi Britannian tappio Saksalle vuonna 1940. Se synnytti tarpeen palauttaa joukkojen taistelutahto.

Lawnin mukaan ohjelman tarkoituksena oli saattaa sotilaat tietoisiksi siitä, miksi sotaa oikein käydään ja millaiseen maailmaan sillä pyritään. Britanniassa uskottiin, että tällä tavoin sotilaita kouluttamalla voitaisiin saavuttaa sodan lopputuloksen kannalta merkittävä henkinen etu.

Tämä Ison-Britannian historian mittavin aikuiskoulutusohjelma perustui keskusteluille ja kaikkien sotilaiden osallisuudelle arvoasemasta riippumatta. Koskaan aikaisemmin ei rivisotamiehiä ollut pidetty 
riittävän älykkäinä sodan syiden ja seurausten pohtimiseen. Armeijan hierarkkisuudesta ohjelmassa ei kuitenkaan luovuttu, vaan viikoittaisia keskustelutilaisuuksia johtivat siihen koulutetut upseerit. Ohjelman suurimmaksi kompastuskiveksi muodostuikin riippuvuus ohjaajan kyvystä luotsata tasa-arvoista ja rakentavaa keskustelua sekä kannustaa osallistujia ilmaisemaan mielipiteensä.

\section{Aikuiskasvatuksen yhteys luonnontieteisiin tulisi palauttaa}

Anja Heikkinen kritisoi luennossaan aikuiskasvatuksen ihmis- ja yhteiskuntakeskeisyyttä. Hänen mukaansa aikuiskasvatus on liiaksi sidoksissa käytäntöihin ja politiikkaan, mikä on johtanut luonnontieteiden ja luontoyhteyden torjumiseen. Esimerkiksi maapallon häpeällinen alistaminen, luonnonvarojen liikakäyttö ja teknologian ylikorostunut merkitys nykyihmisen elämässä viestivät vieraantumista luonnosta ja ympäristöstä: kaikesta ei-ihmisellisestä.

Heikkinen peräänkuulutti aikuiskasvatustieteen siirtymistä aktivismista realismiin, mikä vaatii esimerkiksi tieteenalan kriittistä itsetutkiskelua ja ihmisen yksilöllisten kehitysvaiheiden huomioimista myös aikuisuudessa. Hänen mukaansa maailmassa tarvitaan aikaa ajatella, vähemmän teknologisia laitteita ja enemmän toisista huolehtimista. Tämä ei pysäytä ihmiskunnan tuhoa, mutta antaa mahdollisuuden mielekkäämpään elämään.

Kommenttipuheenvuoron Heikkisen luentoon piti professori Heikki Silvennoinen, joka kiitteli yritystä aktivoida yleisöä ajattelemaan syvemmin omaa elämäänsä ja tieteenalaansa. Silvennoinen piti aikuiskasvatustieteen ongelmana sen historiallista kansansivistysperinnettä ja tieteenalan heiveröisyyttä, jotka johtavat tarpeeseen miellyttää tutkimusyhteisöä ja rahoittajia. Tällöin aikuiskasvatustiede kehittyy sitä ohjaavien resurssien ehdoilla ja sivuun jäävät kriittiset kannanotot, joissa vaaditaan huomioimaan ihmisellisen todellisuuden säilymisen ei-ihmiselliset ehdot.

\section{Teemaryhmissä aiheita aatehistoriasta yrittäjyyskasvatukseen}

Tapaamisen kymmenessä teemaryhmässä tarkasteltiin aikuiskasvatuksen moninaisia kysymyksiä ja ulottuvuuksia niin käytännöllisistä kuin teoreettisistakin näkökulmista.

Toimijuuden vahvistaminen aikuisten elämänkentillä -ryhmässä etsittiin uusia keinoja, joilla raivata esteitä ja rajoituksia aktiivisen toimijuuden ja elämänhallinnan tieltä. Esitykset käsittelivät muun muassa valokuvan käyttöä toimijuuden vahvistamisessa sekä hiljaisen osaamisen tekemistä näkyväksi osallistavan ryhmätyöskentelyn keinoin.

Aikuinen oppijana - haasteita ja mahdollisuuksia -ryhmässä pohdittiin aikuisen oppijan tarpeita ja erityispiirteitä, oppimisympäristön merkitystä oppijan tukijana sekä vallan käyttöä ohjaustilanteissa.

Aikuiset ja aikuisuus korkeakoulutuksessa -ryhmässä keskustelua herättivät aikuisiällä suoritetut korkeakoulututkinnot hyötyineen ja mahdollisine haittoineenkin.

Aikuiskasvatuksen filosofia ja aatehistoria -ryhmässä kyseltiin, millaista on hyvä kasvatus ja millainen lienee kasvatustieteen yhteiskunnallinen relevanssi. Yhteiskunnalliset aiheet puhuttivat myös Kansalaisuuteen kasvaminen pluralisoituvassa ja globalisoituvassa maailmassa-ryhmässä, jossa pohdittiin esimerkiksi keinoja aktiivisen kansalaisuuden edistämiseen.

Monimuotoistuvaan työelämään pureuduttiin erityisesti työntekijöiden oppimismahdollisuuksien näkökulmasta teemaryhmässä Sivistys, markkinat ja politiikka globaalistuvan työelämän oppimisessa.

Aikuisten taidot työssä ja arjessa -ryhmässä perehdyttiin tuoreimpaan PIAAC-tutkimukseen ja sen tuottaman aineiston monipuolisiin käyttömahdolli- 
suuksiin. Vapaan sivistystyön teemaryhmässä puolestaan esiteltiin vapaan sivistystyön laajempia hyötyjä arvioineen Benefits of Lifelong Learning (BeLL) -tutkimuksen tuloksia.

Yrittäjyyskasvatus - yhteisöllisyys ja oppimisympäristöt -ryhmässä paneuduttiin yrittäjyyden opettamisen ja oppimisen keinoihin sekä selviteltiin esimerkiksi lapsuuden kasvuympäristön merkitystä menestyvien yrittäjien elämänkululle. Sukupuolen merkitystä aikuiskasvatuksen eri alueilla koulutuspolitiikasta opiskelukäytäntöihin ruodittiin teemaryhmässä Sukupuoli aikuiskasvatuksessa.

\section{Aikuisena kasvaminen - sivistystä, osaamista ja brändäystä}

Tapaamisen päätteeksi kokoontui vielä tutkija Nina Haltian ja tohtorikoulutettava Heikki Kinnarin juontama paneeli pohdiskelemaan, mitä aikuisena kasvaminen tämän päivän yhteiskunnassa oikein merkitsee: tarkoittaako se sivistystä, osaamista vai brändäystä?

Paneelia puhutti erityisesti kysymys siitä, onko itsensä kehittäminen ja ihmisenä kasvaminen pakko vai mahdollisuus. Esimerkiksi työelämävalmennusten kasvava suosio kertoo siitä, että työntekijöiltä vaaditaan jatkuvaa oman persoonan kehittämistä ja itsemarkkinointia.

- Pitää tulla paremmaksi työntekijäksi mutta samaan aikaan pysyä aitona ja kehittää omaa itseään, kiteytti tutkija Katariina Mäkinen Helsingin yliopistosta.

Toisaalta Sivistystyönantajien elinkeinopoliittisen asiantuntijan Piia Alvesalon mukaan oman paikan etsiminen työelämässä voi tarjota mahdollisuuden myös positiiviseen itsetutkiskeluun.

Åbo Akademin professori Petri Salo haastoi kuulijoita pohtimaan, eikö ihminen saa enää vain olla rauhassa ilman jatkuvaa itsensä toteuttamisen, kehit- tämisen ja esittämisen vaadetta. Tampereen yliopiston dosentti Karin Filanderkin mietiskeli, mistä löytyisi tilaa vain olla ja tehdä, ja sen kautta oppia. Myös Auralan kansalaisopiston toiminnanjohtaja Juhani Pörtfors puolusti aikuisten vapautta opiskella ja sivistää itseään omista lähtökohdistaan käsin. Opetus- ja kulttuuriministeriön ylijohtaja Tapio Kosunen puolestaan nosti esiin muun muassa ammattien, työelämän ja osaamisen polarisaation aikuiskoulutuksen haasteina.

\section{Miltä näyttää aikuiskasvatuksen tulevaisuus?}

Tapaamisessa ei keskusteltu vain aikuiskasvatuksen menneisyydestä ja nykytilasta, vaan visioitiin myös tulevaisuutta ja tulevia tutkimustarpeita. Paneelikeskustelussa Juhani Pörtfors kehotti kiinnittämään huomiota murentaviin mahtitekijöihin, joilla hän tarkoitti tieteen, yhteiskunnan rakenteiden ja julkisen keskustelun pyrkimystä määritellä, mikä ihmisen elämässä on oikeanlaista toimintaa. Yhteiskunnan rakenteet nosti valokeilaan myös Piia Alvesalo kysyessään, voidaanko pedagogiikan keinoilla korjata yhteiskunnan rakenteellisia vikoja.

Päivien aikana korostettiin niin ikään tarvetta keskustella tieteenalan perustasta ja perusolemuksesta. Kysymys on tärkeä aikuiskasvatustieteen identiteetin kannalta yhteiskunnan sekä yliopisto- ja tiedepolitiikan moninaisten myllerrysten keskellä. Mikä on aikuiskasvatustieteen tehtävä, ja millä perustein tutkimuskohteet valitaan? Tämä kriittinen teema oli vahvasti esillä ennen kaikkea Anja Heikkisen luennossa, mutta siihen otettiin kantaa myös paneelikeskustelussa.

Esimerkiksi Karin Filander piti arveluttavana, että aikuiskasvatustieteilijöiden keskuudessa syntyy aaltomaisia tutkimusinnostuksia riippuen siitä, millaisille teemoille rahoitusta kulloinkin näyttää myönnettävän. 
Tutkijatapaamisen järjestelytoimikunta, johon kirjoittajien lisäksi kuuluivat Nina Haltia, Suvi Jokila, Tuuli Kaunisto ja Heikki Kinnari, kiittää lämpimästi puhujia, panelisteja, teemaryhmien vetäjiä, ryhmissä alustaneita tutkijoita sekä kaikkia muita päiville osallistuneita onnistuneesta tilaisuudesta. Tutkijatapaaminen osoitti aikuiskasvatustieteen elinvoimaisuuden ja tarpeellisuuden muuttuvassa ja kovenevassa maailmassa- kunhan se vain tulevaisuudessakin vaalii laaja-alaisuuttaan, juurevuuttaan, itse- ja yhteiskuntakriittisyyttään ja humaaneja kasvojaan!
Paula Vitie

tutkimusavustaja

Tarita Riikonen

tutkimuskoordinaattori

Arto Jauhiainen

kasvatustieteen professori

Turun yliopisto 